\title{
Surveying Online Platforms Used in Higher Education During Covid-19 Pandemic in Riau-Indonesia
}

\author{
Asyti Febliza ${ }^{1}, Z_{\text {Zul Afdal }}^{2 *}$, Jimmi Copriady ${ }^{3}$, Dedi Futra ${ }^{4}$, Sri Wilda Albeta ${ }^{5}$ \\ \{asytifebliza@edu.uir.ac.id ${ }^{1}$, zulafdal@fe.unp.ac.id ${ }^{2}$,jimmi.c@lecturer.unri.ac.id ${ }^{3}$, \\ dedifutra@lecturer.unri.ac.id ${ }^{4}$,wilda.albeta@lecturer.unri.ac.id ${ }^{5}$ \}
}

Universitas Islam Riau, Riau 28284 Indonesia $^{1}$, Universitas Negeri Padang, Sumatera Barat 25171 Indonesia ${ }^{2 *}$, Universitas Riau, Riau 28293 Indonesia ${ }^{3,4,5}$

\begin{abstract}
The use of online platforms was inevitable since almost all educational institutions closed due to the COVID-19 outbreak. This study identifies how conducted teaching and learning activities for a year after the university's closure in Riau-Indonesia. An online questionnaire was designed on a google form survey, and the link was shared with 341 students of the Teacher Training Faculty from the three most prominent universities in Riau-Indonesia. As additional data, 15 lecturers were interviewed via WhatsApp chat with open-ended questions. The Survey revealed that video conferences (zoom and google meet), google classroom, and instant messaging (Whatsapp and telegram) were the most widely used platform for online learning. The lecturers interviewed mentioned that they usually combine some media: Instant messaging, video conferences, and LMS platforms, to conduct online teaching. The combination of three kinds of those platforms was more effective in online learning than others.
\end{abstract}

Keywords: Edmodo, E-Moodle, Google Classroom, Online learning platform; Video conferences platform

\section{Introduction}

The coronavirus pandemic has challenged educational institutions all over the world since the first half of 2020. As a result, many countries, including Indonesia, have adopted policies that prohibit all educational practices, forcing the government and related institutions to provide alternative educational processes for educational institutions. As a result, conventional classroom learning and teaching were evaluated, and online learning was implemented. Online learning means a way of instruction in which students and lecturers are physically distant and need a delivery system or technology to mediate the interaction of students and lecturers with learning environments design to reach a significant impact on learning outcomes [1-4]. Interaction between students and lecturers is facilitated using online teaching platforms. In addition, online teaching and learning can be supported by many platforms such as Google Classroom, Zoom, slide, video creator platforms, Cisco Webex, etc. [5,6].

Since the 1960s, video conference (also known as video telephone or telecollaboration) has synchronized video and audio contact between geographical locations. By the 1990s, technical advancements had improved and made videoconferencing facilities more accessible, and the technology was widely used in educational settings [7]. LMS (i.e., google classroom, Edmodo) as asynchronous teaching is a learning management system that aims to simplify making, distributing, and grading assignments [6]. In addition, the most crucial social media for 
computer and mobile communication today are instant messaging and social networks, which allow for a fast exchange of messages. [8].

Indonesia Ministry of Education and Culture (MOEC) implemented a new system in the teaching and learning process as "Online Learning" to avoid the spread of the Covid-19 for higher education since March 2020. As a result, this policy forced most universities in Indonesia to implement teaching and learning activities from a distance or online lectures. Based on the Directorate General of Higher Education (Ditjen Dikti) survey, 98\% of universities have conducted online learning. With this implementation in universities with an established online academic infrastructure, online learning is not a problem.

However, institutions that do not yet have an online academic infrastructure will face difficulties. Some of those obstacles: 1) In terms of learning culture, many lecturers and students are not comfortable using an online learning method. This condition refers to a lack of digital literacy. Therefore, lecturers and students must work hard to become proficient in online learning; 2) Internet network constraints due to the uneven internet access in regions in Indonesia; 3) Not all universities have online learning infrastructure and platforms [9].

MOEC (2020) has surveyed the implementation of online learning in some universities in Indonesia. Surveyed data was collected from each university. The results were in Universitas Negeri Medan (Unimed), the platform used for online learning is the Sipda application (sipda.unimed.ac.id) by 49\%, Google Classroom 36\%, Edmodo 2\%, use of Schoology by 2\%, and use of teleconference: Zoom Meeting/Google Meet/Webex by $12 \%$. In addition, Universitas Terbuka (UT) applies Tuton and Tuweb to accomplish with Microsoft Teams to conduct online learning. The average number of online learning implementation in Institut Teknologi Sepuluh Nopember Surabaya (ITS) was $30 \%$ by email, Whatsapp, and other social media application, then $70 \%$ by using myITS Classroom (Classroom.its.ac.id) in which $60 \%$ teleconference and the rest asynchronous. Furthermore, Universitas Gadjah Mada (UGM) provides learning application elok.ugm.ac.id and elisa.ugm.ac.id for online learning.

On the other hand, Institut Teknologi Bandung uses LMS Edunex as an online platform, then Universitas Udayana Online lectures during the Covid-19 pandemic at Udayana University go through 3 (three) systems, namely ELSE U, PJJ e-Learning, and OASE. State Universities dominate the implementation of online learning, but Private Universities have also implemented online learning. For example, Trisakti University already has facilities for online learning using the LMS and video conference platforms [9]. The MOEC survey utilized online learning for higher education in teacher training faculty in Riau had not been described; therefore, this study identifies how teaching and learning activities were implemented. What were online learning platforms used by universities in Riau?

\section{Research Methods}

This survey research used a mixed-method consisting of quantitative and qualitative data; the quantitative information came from a questionnaire. The qualitative information came from interviews with lecturers. The procedures in this study were:

\subsection{Construct research instrument}

Instruments in this study were an online semi-structured questionnaire and a structured interview. The questionnaire was designed on a google form survey with several alternative answers to choose from more than one. Respondents could add their answers if available 
answers did not match them. The accuracy and consistency of research instruments become a significant aspect of collecting valuable data. Thus, both instruments in this study were validated by experts' judgment and internal consistency reliability obtained through Cronbach's alpha [10].

\subsection{Recruit and measure sample}

This study was implemented in three most prominent universities in Riau, namely: Universitas Riau (UR), Universitas Sultan Syarif Kasim Riau (UIN Suska Riau), and Universitas Islam Riau (UIR). The sampling technique in this study was purposive sampling with a disproportionate stratified method [11]. The sample chosen considered that the three largest universities have various study programs and many students. Thus, the total sample was obtained 341 consisting of 125 students from UR, 68 UIN students, and 148 UIR students from science and social study programs. Furthermore, interviews were conducted with 15 lecturers (each university consists of 5 lecturers) from science and social groups.

\subsection{Data collection}

Data was collected online, in which the questionnaire link was sent to respondents via WhatsApp. The online questionnaire identified online learning platforms used by lecturers during the Covid-19 outbreak since a year of remote learning implementation. In addition, openended questions were used to interview the lecturers about their perceptions of online media and confirm students' responses after students' responses were collected. Finally, lecturers were interviewed by WhatsApp chat with open-ended questions.

\subsection{Data analysis}

Data in this study consisted of questionnaires and interview responses. The results of the questionnaire were calculated by using percentage formulation as [12]:

$\mathrm{f} \quad$ frequency

$$
\% \text { response }=\frac{f}{N} \times 100 \%
$$

$\mathrm{N}=$ Total number of participants

Moreover, interview responses were analyzed descriptively with narrative interpretation to confirm students' responses and obtain the lecturers' view of online learning platforms.

\section{Result and Discussion}

Based on the questionnaire results sent to students, obtain information about the percentage of video conferences (zoom and google meet), Google Classroom, Edmodo, and Whatsapp or telegram use shown in Figure 1. 


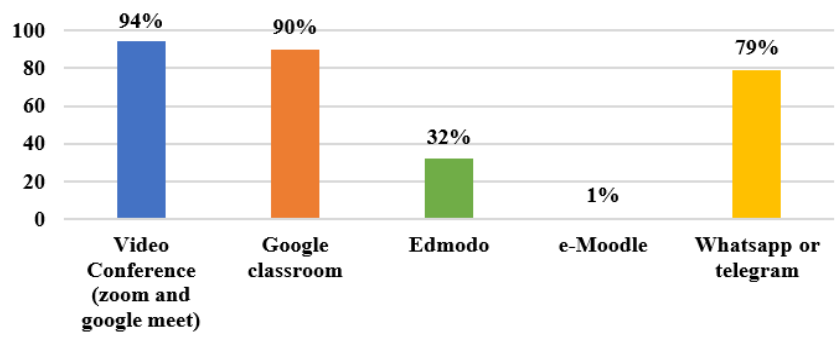

Fig 1. The percentage of online learning platforms use

Figure 1 shows that video conference platforms became the most widely used in remote learning and peaked at $94 \%$. It indicated that video conference (zoom and google meet) was a good and valuable platform for teaching during Covid-19 [5,7]. The second platform was Google classroom with $90 \%$, and WhatsApp became the third choice with $79 \%$. On the other hand, the use of the Edmodo platform was only $32 \%$, and e-Moodle obtained the smallest percentage as $1 \%$. Those results were confirmed with the lecturers using WhatsApp interviews, and the results proposed that lecturers prefer to use video conferences because they could explain lecture materials directly, such as face-to-face teaching but in a virtual environment. Besides that, students were able to ask and clear their doubts about the lecturer's explanation. This finding appears aligned with the research result that $63,8 \%$ of learners clarified their doubts when video conferences took place [13].

In addition, lecturers also gave information that they choose free access online platforms because their campus is starting to create its online learning platforms and expecting to be used in the following semester. Furthermore, researchers were grouping the data in terms of video conferences (zoom and google meet), LMS (google classroom and Edmodo), and instant messaging (Whatsapp and telegram), as well as the combination of those platforms in remote learning. Finally, the data about how the lecturers use platforms is described in figure 2.

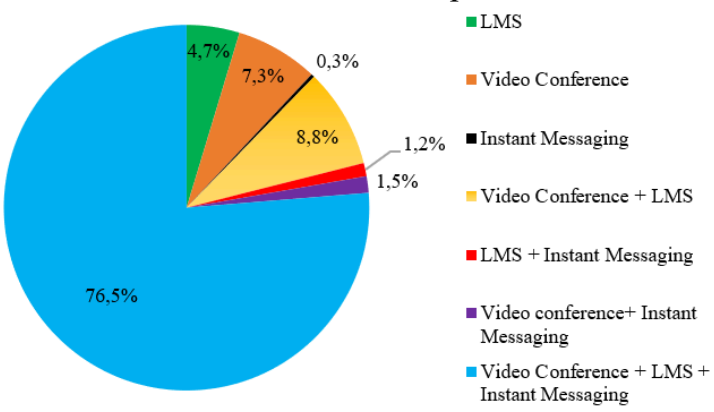

Fig. 2. How the lecturers use platforms

According to Figure 2, more than three-quarters $(76,5 \%)$ of lecturers combine video conference, LMS, and Instant messaging to teaching. In addition, from the interview, the lecturers argued that the combination of three platforms was helpful for them in which they used instant messaging to inform students about schedule, video conference to explain lecture material, and LMS to give the assignment. Moreover, instant messaging, such as WhatsApp, makes lecturers more accessible and more extensive to communicate with students and making discussion groups. Both lecturers and students always check their phones for messages and always respond to the arrival sound $[14,15]$. 
Besides that, In the educational field, instant messaging and social networks can make it easier to deliver educational results, foster positive relationships, and promote a sense of belonging, identity building, and self-esteem [8]. Furthermore, LMS was the best way of utilizing lockdown time, allows students to use material anytime and anywhere without time limit, simplifies creating, empowers learners and teachers too; communicate giving information, assignments, post a note, assignments submission and projects [6,16-19]. On the other hand, video conference platforms are user-friendly, allowed learning in personal space, provide freedom to choose which lecture to attend, no compulsion of physical presence at the teaching institute, students will watch and listen to a teacher in one or more locations in real-time. $[13,20,21]$.

Furthermore, Figure 2 showed that video conference and video conference with LMS obtained the average percentage of 7,3\% and 8,8\%, respectively. Meanwhile, LMS reached $4,7 \%$, then Video conference with instant messaging, LMS with instant messaging, and instant messaging became the three lowest percentage at less than 1,5\%. Lecturers confirmed that they tend to use three kinds of the platform in terms of video conference, LMS, and instant messaging to make their teaching and learning process effective effectively.

Moreover, lecturers could minimize the obstacles of online learning by using a combination of those platforms; for example, the lecturer could communicate with students via instant messaging about lecture schedules and explained lecturer materials by video conference and upload assignment in LMS. Lecturer explanation in video conference meeting recorded as lecture material for Students getting obstacles and students could access it in LMS or lecturer sent it by instant messaging.

Therefore, lecturers' implementation of online learning continuously improves since the beginning of the university closure until now to get better learning. In addition, lecturers also stated that both lecturers and students are becoming more comfortable with online learning.

\section{Conclusion}

Various kinds of online platforms to support the teaching and learning process was adopted by the lecturers. The most prominent platforms were video conference, LMS, and Instant messaging used by lecturers in remote learning during Covid-19 in Universities in Riau. The lecturers agreed that a combination of those three platforms minimizes online learning barriers. Moreover, lecturers and students are becoming more comfortable with online learning.

\section{Acknowledgments}

The authors give gratitude to the Directorate of Research and Community Service-Ministry of Research, Technology, and Higher Education (DRPM-Kemenristekdikti) for completely funding the research that led to the publication of this paper.

\section{References}

[1] Wang C H, Shannon D M and Ross M E 2013 Students' characteristics, self-regulated learning, technology self-efficacy, and course outcomes in online learning Distance Educ. 34 302-23

[2] Wilde $\mathrm{N}$ and Hsu A 2019 The influence of general self-efficacy on the interpretation of vicarious experience information within online learning Int. J. Educ. Technol. High. Educ. 16

[3] Bower M 2019 Technology-mediated learning theory Br. J. Educ. Technol. 50 1035-48 
[4] Gonzalez T, de la Rubia M A, Hincz K P, Comas-Lopez M, Subirats L, Fort S and Sacha G M 2020 Influence of COVID-19 confinement in students' performance in higher education arXiv 125

[5] Ramadani A and Xhaferi B 2020 Teachers' Experiences with Online Teaching Using the Zoom Platform with EFL Teachers in High Schools in Kumanova SEEU Rev. 15 142-55

[6] Sheelavant S 2020 Google classroom - An effective tool for online teaching and learning in this COVID era Indian J. Forensic Med. Toxicol. 14 494-500

[7] Krutka D G, Carano K T, Cassell L, Lavoie M and Davidson-Taylor K 2019 Wise Practices and Intercultural Understandings: A Framework for Educator Videoconferencing J. Res. Technol. Educ. 51 356-76

[8] Oseni, Kazeem Oluwakemi., Dingley, Kate., \& Hart P 2018 Instant Messaging and Social Networks - The Advantages in Online Research Methodology Int. J. Inf. Educ. Technol. 8 5662

[9] Pendidikan Tinggi D J 2020 Buku Pendidikan Tinggi di Masa Pandemi COVID-19

[10] Gay L R, Mills G E and Airasian P 2012 Competencies for Analysis and Applications 10th Edition vol 6

[11] Sugiyono 2015 Metode Penelitian \& Pengembangan (Research and Development) (Bandung: Alfabeta)

[12] Febliza, A., Afdal Z 2015 Statistika Dasar Penelitian Pendidikan (Pekanbaru: Adefa Grafika)

[13] Sharma K and Sarin J 2021 Dissection of Learning Opportunities and Obstacles While Learning Through Video Conferencing Platform (VCP) - During Covid 19 Lockdown Indian J. Forensic Med. Toxicol. 15 155-62

[14] Lauricella S and Kay R 2013 Exploring the use of text and instant messaging in higher education classrooms Res. Learn. Technol. 21 1-17

[15] Sutikno T, Handayani L, Stiawan D, Riyadi M A and Subroto I M I 2016 WhatsApp, viber and telegram: Which is the best for instant messaging? Int. J. Electr. Comput. Eng. 6 909-14

[16] Balasubramanian K, Jaykumar V and Fukey L N 2014 A Study on "Student Preference towards the Use of Edmodo as a Learning Platform to Create Responsible Learning Environment" Procedia - Soc. Behav. Sci. 144 416-22

[17] Shaharanee I N M, Jamil J M and Rodzi A S S M 2016 The application of Google Classroom as a tool for teaching and learning J. Telecommun. Electron. Comput. Eng. 8 5-8

[18] Iftakhar S 2020 GOOGLE CLASSROOM: WHAT WORKS AND HOW? J. Educ. Soc. Sci. 312 8

[19] Mafa K R 2018 Capabilities of Google Classroom as a Teaching and Learning Tool in Higher Education Int. J. Sci. Technol. Eng. 5 30-4

[20] Malinovski T, Trajkovik V and Vasileva-Stojanovska T 2018 Impact of different quality of service mechanisms on students' quality of experience in videoconferencing learning environment Turkish Online J. Distance Educ. 19 24-37

[21] Lowenthal P R, Snelson C and Dunlap J C 2017 Live synchronous web meetings in asynchronous online courses: Reconceptualizing virtual office hours Online Learn. J. 21 177-94 